\title{
English and Mauritian Creole: A Reflection on How the Vocabulary, Grammar and Syntax of the Two Languages Create Difficulties for Learners
}

Kobita Kumari Jugnauth*

Palma Road, Quatre-Bornes, Mauritius

Corresponding Author: Kobita Kumari Jugnauth, E-mail: kobitan@gmail.com

\section{ARTICLE INFO}

Article history

Received: November 11, 2017

Accepted: January 11, 2018

Published: March 01, 2018

Volume: 7 Issue: 2

Advance access: February 2018

Conflicts of interest: None

Funding: None

\begin{abstract}
The purpose of this paper is to reflect on the various linguistic reasons that cause Mauritian students to experience difficulties while learning English. As Mauritius is a former British and French colony, most Mauritians are bilinguals. Both English and French are compulsory subjects up to Cambridge O'Level. English is the official language and also the language of instruction but French is much more widely used and spoken. Also Mauritian Creole is the mothertongue of the majority of Mauritians. This linguistic situation impacts heavily on the teaching and learning of English both at primary and secondary level. Often, students encounter a number of problems at the vocabulary and grammatical level; these are due to the linguistic specificities of both English and Mauritian Creole. Today, the different types of 'Englishes' emerging around the world, are making it increasingly confusing for teachers to teach this language and for learners to learn it.
\end{abstract}

Key words: Learning English, Mauritian Creole, Difficulties, Linguistic, Vocabulary
In her paper entitled 'English as a Lingua Franca', Jennifer Jenkins from the University of Southampton claims that about $80 \%$ of English speakers are non-native - which de facto implies that this large volume of speakers have a mothertongue of their own and use English mostly as a means of interacting with native and non-native speakers. Bearing this in mind, it would be fair to say that the teaching of English in schools should be centered more on a communicative approach than on an academic one. Unfortunately, in the current trend, the gap between English taught through traditional English textbooks and English as a contact language between speakers having different mothertongues, is deepening. Young learners are finding it increasingly difficult to overcome such differences while teachers are struggling to make English more appealing and contextual despite curriculum constraints. Nevertheless, many young learners find it hard to acquire English and this may be due to a number of linguistic and non-linguistic factors.

While learning English, many Mauritian learners face problems similar to their multilingual Indian, Malaysian or Nigerian counterparts. India, Malaysia and Nigeria being former British colonies, have given an official status to English while the local people have various mothertongues - a linguistic context which impacts heavily on the acquisition of English. It is beyond any doubt that the linguistic specificities of English language and those of French-based Mauritian Creole (MC), French and Bhojpuri spoken in Mauritius - raise concern among Mauritian teachers and learners. So, what makes English such a difficult language to acquire to Mauritian learners?

\section{VOCABULARY}

- Collocations - associations of words - in MC can be problematic when transferred to English and vice-versa. An example would be 'so labus sal' which means 'he/she speaks in a vulgar way' but the literal translation in English would be 'his/her mouth is dirty'. Similarly, in MC, people commonly use the expression 'bwar ãnba labutik' which literally translates as 'drink under the shop' thus causing Mauritians learners to experience difficulty translating this. In the same way, typical collocative words in English but non-existent in French or MC may also prove to be difficult to assimilate to the young Mauritian learner. Thus common expressions such as 'blind date' have no counterpart in languages commonly spoken in Mauritius - thereby making the acquisition of English vocabulary difficult.

- Blending is a process causing the quick expansion of the English language. This can mostly be witnessed in language used by media. It is not uncommon to find hitherto unseen words such as 'fantabulous' and 'infotainment'. Blended words may be used both in formal and informal contexts but in the case of the young learner, using newly coined terms can be tricky and its use may 
be inappropriate. This definitely undermines the confidence of the learner.

- Compounding may be common in English and French. Nevertheless this is rather unusual in MC. Teachers of English language in Mauritius encounter difficulties with word formation exercises. Affixation may create confusion as learners juggle with words like 'motherhood', 'simplicity', 'indecisive', 'impartial', 'abnormal', 'wilderness' - making prefixes and suffixes seem arbitrary additions to root words. It is easy to explain that the prefix 'im' is generally placed before the plosives ' $b$ ' ' $p$ ' and ' $m$ ' and 'in' is placed before other letters but what about prefixes 'in' and ' $u n$ ' in the words 'insecure' and 'unspoken'? Why 'in' in the first case and ' $u n$ ' in the second case? Also fully compounded words like 'colorblind' are inexistent in MC and such lexical items existing in the English vocabulary cannot be easily integrated into learners' lexicon.

- Idioms, clichés, proverbs and expressions are unarguably a serious concern among Mauritian learners. A learner can understand expressions like 'better days' or idioms like 'bell the cat' but can he/she make appropriate use of such expressions? Other idioms like 'Let sleeping dogs lie' also have no counterpart in MC. On the other hand, MC expressions and idioms like 'fer labus du'- an expression directly imported and translated from Hindi (which itself is culturally relevant to the Indian context) - literally translates as 'make one's mouth sweet', meaning 'giving sweet delicacies as a token of happiness'. The literal translation of this expression into English may make perfect sense to the Mauritian learner but will certainly make no sense to other native and non-native speakers of English. Learners also come up with expressions like 'he returned him double' which is a literal translation of the MC idiom 'ran li so dub' meaning 'punish someone twice as much'.

- The idiosyncracies and irregular forms in English are yet another major issue Mauritian teachers and learners have to deal with carefully. How readily can an eightyear old accept that the plural of 'foot' is 'feet' but that the plural of 'boot' or 'root' are not 'beet' or 'reet' respectively? Or, why should the past tense of 'strut' be 'strutted' whereas that of 'cut' is unchanged? How far can an English teacher successfully teach such idiosyncracies to his/her class?

- False friends and homophones cause a considerable confusion among learners. A notable example is the English word 'sensible' and MC word 'sãnsib' (borrowed from French 'sensible') meaning 'sensitive' both in French and MC. Learners often use the word 'sensible' when they actually mean 'sensitive'. Teachers also routinely encounter expressions such as 'passed a command' which is a literal translation of MC 'pas koman' - the meaning of which is 'to order'. Other examples include 'my day passed well' - literal translation of MC 'mo lazurné in pas byĩn' which actually means 'my day went well'. Also 'they profited of this moment to steal' is a literal translation of 'zot in profit sa momãn la pu kokĩn' - meaning 'they seized this opportunity to steal'. Homo- phonic words such as 'leek' and leak' - and even 'loose' and 'lose' are very commonly mistaken. Orthography is also greatly hampered due to homophones or words having almost similar phonetic pronunciation thereby causing difficulties to the learner. Few students understand the grammatical difference between 'practice' and 'practise' because MC is mostly a spoken language and even in its written form homophones are lacking.

\section{GRAMMAR AND SYNTAX}

- Phrasal verbs and adverbial phrases which are distinctive features of English language, are commonly mistaken by learners. Few learners distinguish between 'look for', 'look at', 'look after' or 'look into'. Also, it is quite common for an English teacher to come across structures such as 'she was walking slowly slowly', a feature that is typical of adverbial phrases in MC, derived from Bhojpuri and Hindi. Some verbal tenses may translate differently from MC to English. The syntactic rule If + simple past tense is followed by conditional, is not always relevant in MC. In fact in MC, both of the following forms are acceptable: 'si to ti al laba, to ti pu truvé' and 'si to ti pu al laba, to ti pu truve'. Both sentences translate as 'if you went there, you would see'. The syntactic rule in $\mathrm{MC}$ is either If + simple past tense is followed by conditional, or If + conditional is followed by conditional.

- Passive Form is rather unnatural and hardly used in MC. This can surely explain why students find it difficult to convert active into passive sentences. MC also favors clauses without a subject. An example would be 'ena buku zafer pu dekuver' which can be literally translated as 'has many things to discover'. Students commonly translate it as 'there has many things to discover'. Also the impersonal MC form 'ti' meaning 'was' is often wrongly translated - an example is 'ti pé fer nwar' translated as 'it was making dark' (it was dark) while 'ti ena' can be translated both as 'there was' or 'there had been' - thereby causing confusion about the verb tense.

- The most interesting and significant syntactic form that causes problems to the Mauritian learners are the MC verbs 'fer' (to make) and 'ganyé' (to get). Gilbert (1980) states that pidgins and creoles often show reluctance or difficulty in enlarging the vocabulary which leads to a strong extension of meaning in some words. This is true of the 2 verbs mentioned above. Here is a list of different semantic uses of the same 2 verbs - the original MC sentence followed by the way learners translate it - and the actual meaning of the sentence (given in brackets):

- mon fer brushing - I made brushing (I had a hairbrush)

- $\quad$ li fer zes - he/she makes gestures (he/she shows off)

- $\quad$ nune fer party - we did a party (we organized a party)

- $\quad$ zanfan fer parey - children make same (children do the same)

- $\quad$ zon fer ban grup sĩnk - they did groups of five (they settled in groups of five) 
- $\quad$ fer plis aktivité - make more activities (do more activities)

- $\quad$ zone fer laké - they made a line (they queued up)

- $\quad$ mone gagn kut delo - I received sprinkling of water (I was drenched by a jet of water)

- $\quad$ mone gagn curan - I got electricity (I got electrocuted).

Interestingly, both Creole and English have much in common regarding other syntactic and grammatical structures but learners are not always able to pick those up in order to apply them correctly while learning English. Contractions occur naturally in MC - 'kapav' meaning 'can' becomes 'kav', 'mo ulé' meaning 'I want' becomes 'mo lé' and 'mo fine alé' meaning 'I went' becomes 'mone alé' but learners seem to have a hard time using proper contracted forms such as 'weren't' in English.

Here are a few other authentic examples of wrong use of English, extracted from learners' scripts that show a heavy influence of $\mathrm{MC}$ in terms of vocabulary and grammar:

- Wrong use of preposition: she stays in the internet

- $\quad$ Adjective used as verb: she absent school

- $\quad$ Elliptical sentences: ... but not any changes

- Double negatives: they don't have nothing

- Impersonal form: there have many sessions

- Comparative form: she likes to surf many more than read

- Vocabulary: he is always on phone

- Vocabulary: their hair was open

- Vocabulary: I did my toilette

- Vocabulary: I like to live personal

- Vocabulary: Food was well put on plates.

\section{LANGUAGE USED IN MEDIA AND SOCIAL SITES}

4. Language used in media and social sites also brings about its share of confusion and difficulty to learners. Today, English is unmistakably the preferred language in social media. People of different nationalities choose to relate to each other in English on sites such as Twitter, Facebook and Instagram. English also largely dominates the world of show-business and entertainment. And yet, the English used in these domains often remotely looks like the English being taught from traditional textbooks.
Young learners are often unable to adjust to such differences and may often find themselves at a loss, specially when it comes to taking written English language examinations.

There are, without any doubt, other non-linguistic factors that influence the teaching and learning of English in Mauritius and elsewhere in the world - factors which may be of political, cultural or socio-economic nature and which make it difficult for non-native speakers of English to learn this language. But many have found their own way of overcoming such difficulties. As David Crystal points out, Nigeria has 'adopted' then later 'adapted' English language to suit its cultural context. According to him, in a country where more than 500 languages are spoken, English was adopted as the official language and about 50 years later, $15000 \mathrm{Ja}-$ maican and 10000 South African words were added to suit the local context. Commenting on the possible future of English, researcher David Graddol cites English as "being at the leading edge of technological and scientific development, new thinking in economics and management, new literatures and entertainment genres." He believes that a lingua franca requires at least a minimum set of standards but paradoxically new 'Englishes' are constantly emerging. So the question now is how must the teaching and learning of English be carried out where non-native speakers of English are concerned?

Note: The alphabet and pronunciation of $\mathrm{MC}$ in this article follows the orthography available on www.omniglot.com

\section{REFERENCES}

Gilbert, G.G. (1980) Pidgin and Creole Languages - Selected Essays by Hugo Schuchardt: Cambridge University Press

Jenkins, J. (2008). English as a lingua franca. JACET $47^{\text {th }}$ Annual Convention. Waseda University, 11-13 September (2008). http://www.jacet.org/2008convention/JACET2008)_keynote_jenkins.pdf(Accessed April 5, 2017)

Graddol, D. (1997). The Future of English [Online] Available at https://www.teachingenglish.org.uk/article/future-english (April 17, 2017)

Ives-Keeler, K. (2014). What's the future of English? [Online] Available at https://www.britishcouncil.org/voices-magazine/whats-future-english ( April 20, 2017) 